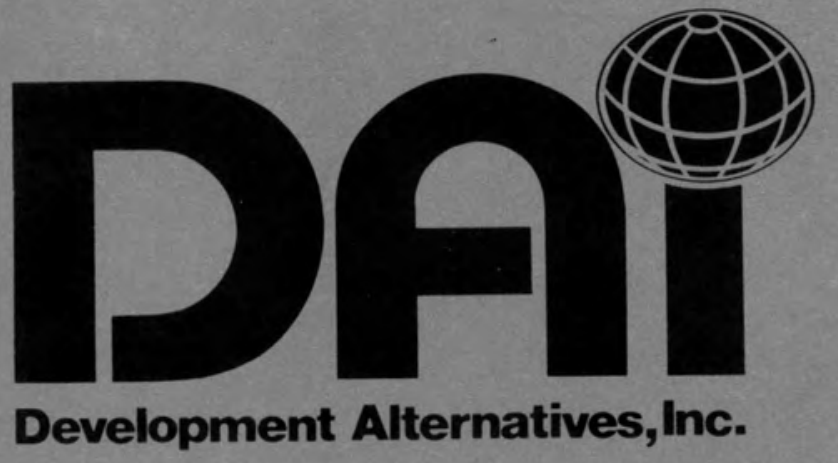




\section{AGRICULTURAL SECTOR SUPPORT PROJECT PRIVATE SECTOR AGRIBUSINESS}

Trip

Report

Bamyan and

Parwan

\section{Provinces}

Agricultural Sector Support Project

Private Sector Agribusiness

Prepared by Development Alternatives, Inc., and the office of the AID Representative to Afghanistan under Contract Number 306-0204-C-00-9829-00.

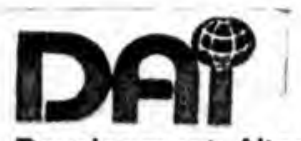

Development Alternatives, Inc.

4 A-C Park Avenue, University Town, Peshawar, Pakistan 


\title{
AGRICULTURAL SECTOR SUPPORT PROJECT PRIVATE SECTOR AGRIBUSINESS
}

TRIP REPORT

\section{BAMYAN AND PARWAN PROVINCES}

\author{
PREPARED BY \\ DEVELOPMENT ALTERNATIVES, INC. \\ FOR THE \\ OFFICE OF THE USAID REPRESENTATIVE TO AFGHANISTAN
}


TABLE OF CONTENTS

Page

I. Introduction....................... 1

II. Survey Report on Bazaars................ 2

A. Methodology ...................... 2

B. Road and Transport Conditions............ 3

C. General Conditions in the Bazaars.......... 4

1. Bazaars in Pakistan.............. 4

2. Bazaars in Wardak Province.......... 5

3. Bazaars in Bamyan Province........... 6

4. Bazaars in Parwan Province........... 11

D. General Comments on Bamyan and Parwan Provinces....................... 12

E. Specific Comments.................. 13

III. Conclusions...................... 13

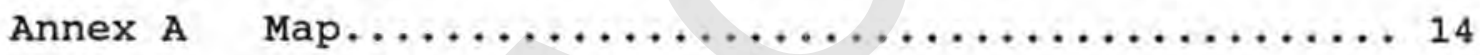




\section{INTRODUCTION}

The goals of Survey IV were to:

- Classify and confirm certain issues relating to travel and transportation to the designated Private sector Agribusiness (PSA) Bazaars;

- clarify fuel prices and availability; and

- Move from the known PSA bazaars, which have been previously surveyed and analyzed, into new territories in several provinces or districts not previously surveyed.

An expatriate (Xavier Bouan) accompanied the survey team of three experienced Afghan surveyors. Team members had previously conducted surveys in Kandahar, Zabul, Kunar and Ghazni Provinces. Results of those surveys were used to determine PSA-designated bazaars.

At the same time that this team visited Parwan and Bamyan Provinces, other surveyors were in Uruzgan, Helmand, Ghazni and Zabul Provinces.

The expatriate responsible for monitoring the Development Alternatives, Inc. (DAI) program in Afghanistan travelled through some provinces where DAI has already initiated activities. He met DAI field workers and saw the program in those provinces. A separate monitoring report on programs in those areas is being prepared.

This trip lasted from June 8 to July 10, 1990. 


\section{SURVEY REPORT ON BAZAARS}

This chronological report includes some bazaars already surveyed and as well as new bazaars. The report relates additional information which may not be included in the results of the survey instrument. The topics discussed in this report include the following:
- survey methodology;
- main points necessary to understand road and transport conditions; and
- the general situation of the bazaars and their political or economic importance.

\section{A. METHODOLOGY}

The survey team was asked to survey eight bazaars in Parwan, Bamyan and Wardak Provinces. The choice of bazaars had been made in Peshawar according to their possible importance before the war.

When the team arrived in the field, four of the listed bazaars proved to have less than fifty shops (Beshud, Shobar, Shashpul and Shorsparsa.) Consequently, they were not surveyed. A fifth bazaar, Jalrez, was also not surveyed because of its proximity to Kabul and attendant security problems.

other bazaars that had not been listed proved to have more than fifty shops and were considered important for DAI purposes. The team therefore decided to survey them. These were the Yakaolang and Doab bazaars in Bamyan Province and Chardi-Ghorband bazaar in Parwan Province.

After arriving at each new bazaar, the team met the local shura or local authority to whom they explained the purpose of their visit. Then, either with or without accompanying local people, the surveyors spent three to four hours in the bazaar to count the number of shops, record prices and obtain other data. The surveyors normally took the opportunity to meet any NGo field workers or other important and reliable key informants in the area.

The part of Survey IV which is additional to survey II was difficult to perform properly for the following reasons:

- Most of the cars in Afghanistan do not have any speedometers. 
- A proper road book on terrain conditions would be quite voluminous since road conditions change every kilometer.

As a result, the surveyors recorded distances, when possible, as determined by truckers, field workers or UN personnel. Terrain conditions were reduced to a simplified form of hilly, mountainous or plain areas.

For this extensive trip the survey team visited or surveyed the following bazaars.

BAzAAR
Hango Rada
Mohammad Khel
Sheikhabad
Chak
Tisak
Beshud
Sand Bank
Shashpul
Bamyan
Yakaolang
Doab
Shobar
Ghorband Chardi
Siagert
Shorsparsa

PROVINCE

Pakistan

Paktika

Wardak

Wardak

Wardak

Wardak

Bamyan

Bamyan

Bamyan

Bamyan

Bamyan

Bamyan

Parwan

Parwan

Parwan
STATUS

Visited

Visited

Resurveyed

Resurveyed

Visited

Visited

Visited

Visited

Surveyed

Surveyed

Surveyed

Visited

Surveyed

Surveyed

visited

\section{B. ROAD AND TRANSPORT CONDITIONS}

During this thirty-five day trip, covering approximately $2,000 \mathrm{~km}$, the survey team made the following observations.

- A road that might be difficult for a pickup or a jeep is easily passable for a truck.

- A road that might be impassable for a jeep is only difficult for a truck.

- The distance in terms of hours is more significant than the distance in terms of kilometers.

- The road to Hazaradjat via the Hajigat Pass is closed from December to March due to snow. An alternative road via Parwan is always passable for trucks.

- The border between Shia and Sunni before Tisak may be difficult to pass and trucks can be delayed if conflicts occur between the two groups. An alternative 
road via Jaghori is frequently used when this occurs (via Dashtch-e-Nawa).

- Tisak bazaar acts as a trans-shipment point for the Hazara truckers who have not been travelling to Pakistan. Jaghori, further south, also acts as a trans-shipment point for Hazara truckers.

0

The Pashtoun truckers from Parwan do not have such trans-shipment points and usually go directly to the Pakistan border without paying any fees.

o

It takes an average of five to six days for trucks coming from Pakistan to Parwan/Bamyan.

o

The normal points to stop over are Hango Rada, Mohammad Khel, Sheikhabad, Tisak, Gardandival, Chardi-Ghorband or Bamyan.

0

There is an increase in check points and taxes for truckers. A truck will pay an average of 5,000 to 10,000 Afghanis between Pakistan and Bamyan or Parwan. Eleven check points are currently reported.

- No NGOs are working to improve this road. VITA is improving roads in Parwan but does not use any cement which is needed when there is flooding. (Cement is available in Pule Khumri.)

0

The most important bazaars under mujahideen control are on the Kabul to Kandahar and Kabul to Bamyan roads.

Al1 roads to Kabul from Wardak or Parwan are open to traffic.

\section{GENERAL CONDITIONS IN THE BAZAARS}

A description of each bazaar encountered will give a flavor and sense of their relative importance. Two photo albums and a video are also available to assist in understanding their physical appearance and levels of trade. All bazaars listed were surveyed unless otherwise noted.

\section{Bazaars in Pakistan}

- Hango Rada: This bazaar is a truck crossing point for most of those going to Ghazni, Wardak, Bamyan and Parwan. It is the first Afghan bazaar on the border with a high level of trade. Currently more than 100 vehicles are stationed here. A previous survey team has studied this bazaar. (See DAI/ASSP Survey IV, May 1990.) It was visited but not surveyed on this trip. 
- Mohammad Khel: This bazaar is halfway between Hango Rada and Sheikhabad, and trucks use it as a stopover point. It has nearly 100 shops and is also on the route to Yahya Khel. It was visited but not surveyed.

\section{Bazaars in Wardak Province}

- Sheikhabad: Situated on the Kabul-Ghazni highway, this bazaar is relatively new (2 years old). Its level of trade increases or decreases according to the situation in Durani bazaar $(200 \mathrm{~km}$ from Kabul). This year it is expanding and people are building new shops. It is mostly used as a stopover point for trucks and a transtrans-shipment point towards Kabul. The lodges are consequently the most important things in this bazaar. There are currently 100 vehicles staying overnight in this bazaar, which is controlled by Jamiat, HIA, Harakat and Mahaz.

According to local people, ten to twenty lorries of urea are transported daily towards Kandahar. Twenty to 50 tractors are also transported weekly towards Kandahar. These tractors are made in the USSR and purchased for 1,400,000 Afghanis in Kabul and supposedly sold for $1,1000,00$ rupees in Chaman. Diesel is in abundance in Sheikhabad (one rupee per liter). Operation Salam distributed some wheat here and many people came from Kabul for this reason.

Due to its level of trade and situation, DAI chose Sheikhabad to implement PSA activities. The PSA bazaar representative rented an office in Dasht-e-Top located seven kilometers from Sheikhabad. (See Monitoring Report.)

Chak: This bazaar was previously surveyed in April 1990. At a distance of $40 \mathrm{~km}$ from Sheikhabad, it takes about two hours to reach a good gravel road. This bazaar is off the main road with shops of much less importance than in Sheikhabad. It has, however, a strategic position on the road to Hazaradjat and Parwan.

This bazaar does not act as a trans-shipment point and is used only by local people. Trucks pass through but rarely stay overnight as they proceed directly to Tisak, the next bazaar.

The bazaar is provided with electricity as the Band-eChak, built by the Germans before World War II, is still working. It has a 1200 megawatt capacity but only one turbine is now working producing 300 
megawatts. The Kabul government continues to pay salaries to the six persons who have run the power station for the last 20 years. The mujahideen have guaranteed that they will not steal the machinery for sale in Pakistan. The power station, as well as most parts of Chak, are under HIA control. Jamiat is also present.

Chak has no refugees and agricultural land is intact except for a few areas of land abandoned for lack of the water pumps used before the war. Four DAI field extension workers are contributing to assistance in agricultural techniques. The number of orchards has increased in the past two years. DAI contributed this year by sending 40,000 trees to the area. (See Monitoring Report.) This area is expected to have strong potential for fruit export in a few years.

- Tisak: This bazaar is located $70 \mathrm{~km}$ from Chak, about five hours for a truck. Tisak is the first bazaar found in Hazara territory. Situated just after a HIA check point, Tisak acts as a trans-shipment point for most of the Hazaras. There are only 40 shops and 12 hotels. This bazaar expects to have more than 80 shops in one or two months. Pashtoun truckers going to Parwan use it as an overnight stopping point. It is controlled by Hezbe Wahadat (Shia). It was visited but not surveyed.

- Beshud: This was supposed to be an wolaswali and an important place but it has nothing more than 20 shops and five hotels on either side of the road. There is no workshop and trucks do not stop here. It was visited but not surveyed.

\section{Bazaars in Bamyan Province}

- Sand Bank: A small bazaar with 35 shops and seven hotels just after the Hajigat Pass on the road to Bamyan. This bazaar is used by truckers as an overnight stopping point. It was visited but not surveyed.

- Shashpul: Not more than five hotels and 10 shops at the crossroads going to Bamyan, Doab, Ghorband* and Beshud. It was visited but not surveyed.

- Bamyan: The most important bazaar in the province with 509 shops and a high level of trade. This area was liberated in June 1988 and since then has been administered by an Islamic shura (MIFA, HIA, Jamiat and the Hezbe Wahadat which consists of eight Iranian 
parties plus Harakat Mosheini).

Shia and Sunni are found equally in Bamyan and the only population movement is migration towards Iran or Kabul for economic reasons.

Mines are still present near the Bamyan airport. Otherwise the situation is quiet and most of the fields are cultivated.

Commodities are coming from Kabul for Roghan oil, Pakistan for wheat, and Mazaar for diesel and fertilizer. Due to floods in June the route to Mazaar was closed and the price of diesel increased.

The economy is very much related to agriculture. Some agricultural features are:

- Rivers are the principle source of irrigation water. Certain rivers become very low or critically dry in late summer and crops are often damaged when this occurs.

- Wheat, potatoes, barley, alfalfa, and mung beans are the most important area crops. Other grains and vegetables are grown to some extent.

- A well established rotation pattern exists in the area.

$\begin{array}{ll}\text { Mung beans } & \text { 1st year or Wheat } \\ \text { Barley } & \text { 2nd year or Mung bean } \\ \text { Wheat } & \text { 3rd year or Wheat }\end{array}$

Farmers are increasingly replacing mung beans with potatoes and wheat which, along with animals, provide the greatest income for farmers.

- Planting time falls between March 1st and early May depending on the crop. Harvest is in mid-July for barley, and lasts through october for potatoes (the only important commercial vegetable in the area). 


\begin{tabular}{|l|l|l|}
\hline Planting Date & Crop & Harvesting Date \\
\hline March-April & Wheat & Early Aug to late Sept \\
Early-March & Barley & Mid July to Mid Aug \\
March-April & MungBeans & Early Oct to late \\
April-May & Potatoes & Early Oct to late oct \\
\hline
\end{tabular}

o

Fertilizer is considered necessary for the soil in the Bamyan general area. Most farmers felt financially able to pay for commercial fertilizer if they could secure it.

- To a certain extent there is a system of barter exchange between local farmers.

- There is no machinery reported in this area.

- Swedish Committee surveyors and field workers reported that $10 \%$ of the farmers have more than five jeribs of land while $90 \%$ have between one and five jeribs.

- The area exports poplars and animals to Kabul. (A local veterinarian reports 50,000 sheep and 20,000 cattle in the Bamyan District.)

The Bamyan bazaar is well equipped for farmers, with large amounts of urea arriving from Kabul at a cheap price of 1,600 to 2,000 Afghanis per $50 \mathrm{~kg}$. The farmers use fertilizers extensively. Pesticides and fungicides are also available in the bazaar. Swedish Committee field workers contribute to the utilization of such products.

The bazaar is open seven days a week, but has a special market day when additional traders come from Kabul or Ghorband. All the area farmers from the mountains visit the bazaar on this occasion and the level of trade and activity increases greatly. Bamyan acts as a trans-shipment point for the province.

- Yakaolang: Situated $115 \mathrm{~km}$ west of Bamyan, it is a five to six hour drive by truck. This road is closed four to five months of the year. Yakaolang can also be reached via the Panjao-Beshud road to the south ten months a year and is preferred by truckers as there are no check point. Panjao bazaar is supposed to have 200 shops but the team could not visit it for lack of transport. 
This area is entirely Shia and controlled by the shura Al-farouk (Hezbe Wahadat) after it was liberated ten years ago. Area people have organized themselves with some local institutions such a Ministries for Education, Security, Health, Finance and Transport.

This bazaar is used by 800 villages in the district (about 50,000 persons).

The most interesting thing in Yakaolang is the creation of a new bazaar. The old bazaar was considered unhealthy with difficulty for trucks in roads and access. The shura decided to create a new bazaar one kilometer from the old one. This new bazaar has 230 shops aligned on each side of the road, with a wide access for trucks. The road has a width of 25 feet. The old bazaar, with 170 shops, still has most of its shops but more and more are moving to the new bazaar.

One shura member, in charge of education and public relations, was helping us and introduced us to the local population. He speaks fluent English. This man has been able to attract several relief projects to Yakaolang:
- MSF with one clinic;
- the Swedish Committee sponsors three of the 13 schools in Yakaolang;
- the Dutch Committee will start a veterinary clinic in two months; and
- more recently, the UN started a food-for-work program to reestablish the irrigation system that had been destroyed by floods and landslides.

The DAI team had a wonderful welcome in Yakaolang with our arrival announced by telephone two hours before we reached the bazaar. One shura member was waiting for us at the bazaar entrance to lead us to the place where we spent two nights.

The local people asked for information about MAP (Medical Assistance Program), an American relief organization present in Yakaolang before the war. They told us that they would be most welcome if they wanted to return.

The agriculture in Yakaolang is about the same as in Bamyan but the people have less land and are consequently poorer. Barley, potatoes, wheat, beans, 
and livestock are about the same as in Bamyan. There is an erosion problem and a lot of cultivated land was destroyed by flooding during the spring. The use of the local coal mines could avoid this, as the farmers are cutting bushes to obtain fuel wood.

Livestock here is more important than in Bamyan and most of the farmers migrate during the summer to high pastures. The activity in the bazaar consequently decreases from June through September.

Yakaolang exports, in addition to potatoes and livestock, some carpets, skins and cumin (1 kg sells for 40 Afghanis). According to some shopkeepers, cumin contributes a great deal to farmer income and its export could be a good source of income for the area.

The shura expressed a great deal of interest in obtaining DAP, wheat seed, and animal husbandry products. Assistance in exporting the previously listed products was also mentioned.

Thirty shopkeepers have trucks in this bazaar for use in exporting these products to Kabul. (They also import fertilizers, diesel, roghan, etc.)

Yakaolang has a beautiful and intact depot for storing 1500 tons of grain or fertilizer. On the day of our visit, the villagers were cleaning it as the UN had promised to send some wheat.

Doab: This bazaar is situated four hours north of Bamyan on the old route of Kabul to Mazar-e-Sharif before the Salang Tunnel was opened in 1964.

Doab, mainly Sunni, is controlled by HIA, Hezbe Khales, and Jamiat. Before the war it was a government bazaar with 40 shops. It now has 60 shops and four hotels. It is still a quiet place but is an interesting bazaar on the road toward the northern provinces. Most of the urea usually comes from Mazar-e-sharif. This road was closed in June due to floods and consequently, traffic decreased a great deal. Doab has a local coal mine and agriculture is only possible in the bottom of the narrow valley or gorge. The crops are the same as in Bamyan but the difference in altitude causes the crops mature one month earlier here.

This bazaar ships commodities to Kamard, which is supposed to have 50 shops. However, the bridge is destroyed and so it was unreachable by car. 

shops on the Bamyan-Ghorband and is not noteworthy. It was visited but not surveyed.

\section{Bazaars in Parwan Province}

- Ghorband Chardi: Situated four hours from Bamyan and one hour from Siagert. The team visited discreetly and for a short time since an internal conflict in the bazaar had resulted in a death the day before the team's visit. The bazaar is totally controlled by HIA and other political parties are not allowed to operate. It has 210 shops and 10 lodges. This bazaar is very much in use by truckers as a trans-shipment point between Kabul, Ghorband, Bamyan and Pakistan.

Ghorband Chardi has a normal quantity of fertilizer, a well equipped veterinary shop, and insecticide and pesticide products.

The area is famous for its orchards with apricots, apples, nuts and fruit being its main exports. Poplar export towards Kabul is also important.

- Siagert: This bazaar is located half way between Kabul and Bamyan, one kilometer from Chardi and two hours from the main highway. It is controlled solely by HIA and has 322 shops.

Similar to Ghorband Chardi, the area is mainly planted with orchards and people are living on the export of fruit, such as apricots, apples and nuts, to Kabul. One shop sells agrochemical products for which there is a great demand.

When possible, the farmers sell fresh fruit to Kabul. Farmers will dry the apricots if the road is closed, but this is not a common practice. One DAI field worker in Parwan who received a training in apricot drying techniques has started training local farmers. The same extension worker also started a poplar nursery two years ago.

There is an obvious lack of adequate supplies to spray fruit trees and crops. There is also a lack of threshers and reapers since the dates for cropping wheat and collecting apricots are the same. Machinery to save time would therefore be of great benefit to farmers. No machinery is reported in the area in spite of cheap diesel and a high level of return for fruit. There are many new fields with nuts and this will be the first production in the area in several years. 
The area has livestock and two veterinary clinics (one supported by the German Afghanistan Foundation and one by the Dutch Committee). The area is also exporting a huge amount of scrap metal.

- Shorsparsa: This bazaar is half an hour off the Ghorband to Bamyan road and is controlled by the Shia Harakat Mosheini. The bazaar has only 28 shops and one hospital (MSF). The bazaar is on the Pakistan to Ghorband road but is not a noteworthy place. It was visited but not surveyed.

\section{GENERAL COMMENTS ON BAMYAN AND PARWAN PROVINCES}

In general, traffic is less dense between Parwan and Pakistan than between Bamyan and Pakistan. In Parwan the main traffic is towards Kabul. Common points for the two provinces of Bamyan and Parwan are:

- Both provinces have a high level of trade.

- The most important bazaars are on the road between Kabul, Bamyan and Charghcharan.

- The political situation is quiet.

- There are no refugees.

- Agricultural land is intact (except for east of Parwan).

- All the surveyed bazaars have more shops than prior to the war.

- Urea is available in quantity in every bazaar at a cheap price of 1600 to 2000 Afghanis.

- Agrochemicals and veterinary products are available in small quantities.

- No improved seed is available in either province.

- There is no or very little machinery.

- Trade for export from these provinces is towards Kabul.

- Trade for import into these provinces is from Pakistan and the USSR. 
Both provinces are exporting poplar and animals towards Kabul and metal towards Pakistan. In addition, Parwan is exporting fruit while Bamyan exports potatoes and a few miscellaneous items.

- Diesel is available in quantity and cheaply. It is approximately one rupee per liter.

- Road and transport conditions are good within the two provinces.

\section{E. SPECIFIC COMMENTS}

People say that prices in Kabul are now very cheap. The UN World Food Programme reports that Kabuli traders are buying a lot in order to bring mujahideen to the cities. It is also reported that the government is sending mullahs, old people, and traders whom nobody will suspect to buy wheat, machinery, etc.

\section{CONCLUSIONS}

This survey details the practicability of DAI implementing activities in Bamyan province (implementation already exists in Parwan Province). The situation is peaceful and trade levels are sufficient. The people of Bamyan Province would welcome such activities.

Currently ongoing ADT activities in Parwan Province could be used to initiate PSA projects. However, HIA controls the area and conflicts are frequent.

This survey took 35 days but if the team had used its own transport the work could have been done in less than 20 days. A great deal of time was spent waiting for transport from one point to another. In Bamyan and Parwan Province the team travelled mainly on trucks. During this time, all films of the trip were stolen as it proved impossible for team members to remain close to the luggage. The team was also caught in a fight between truckers and the local population in one area and was fortunate that no one was hurt.

It is very difficult to monitor and survey while being dependent on local people. Therefore, the expatriate team member, for the sake of security and efficiency, does not envision any further trips without having his own means of transport while in Afghanistan. 


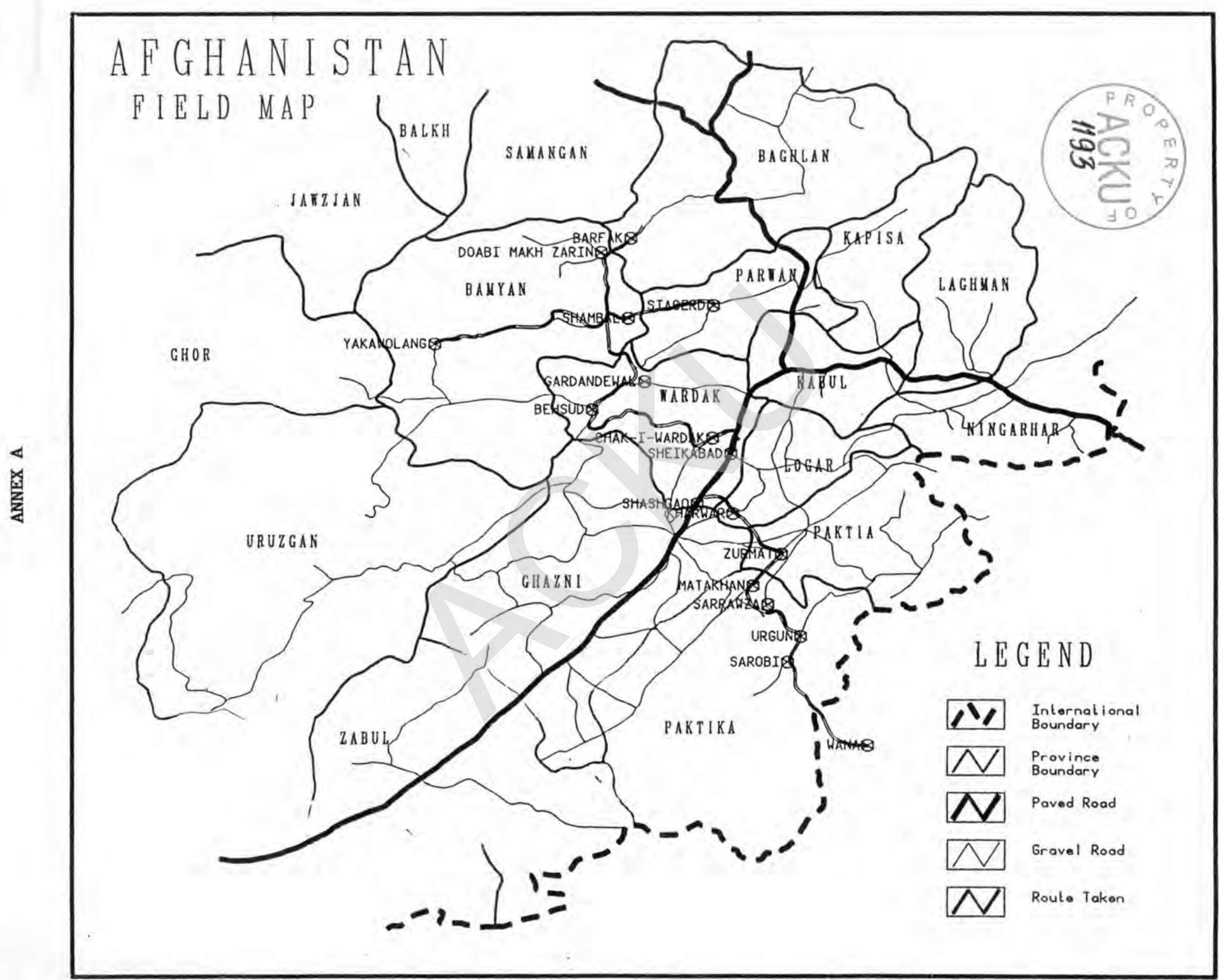

